\title{
Probiotic Potential Test for Lactic Acid Bacterial Isolate from Labi Cattle Gastric Again Low Acidity and Sodium Deoxycholate
}

\author{
I Made Rahma Sanjaya ${ }^{1 *}$, I Wayan Suardana ${ }^{2}$, I Nyoman Suarsana ${ }^{3}$ \\ ${ }^{1}$ Student, Faculty of Veterinary Medicine; ${ }^{2}$ Laboratorium Veterinary Public Health, Faculty of \\ Veterinary Medicine; ${ }^{3}$ Laboratorium Microbiology Clinic, Faculty of Medicine, \\ UdayanaUniversity, Bali \\ *Corresponding Author: imaderahmasanjaya@gmail.com
}

\begin{abstract}
Lactic acid bacteria (LAB) are one of group probiotic bacteria, which have a positive impact on human and animal health. The aim of this research was to determine the potency lactic acid bacterial isolate from LABi cattle gastric as a probiotic that have resistance to low $\mathrm{pH}$ and sodium deoxycholate. The study was started with the cultivation test that aims to made sure uncontaminated isolates of microorganisms, including test for growth response in MRS broth medium, test on catalase production, and Gram stain. Its potency for probiotic development was tested by growing of isolate in MRS broth medium with low $\mathrm{pH}$ conditions $(\mathrm{pH} 2,3,4)$ and in MRS medium supplemented with various concentration of sodium deoxycholate $(0,2 \mathrm{mM}, 0,4$ $\mathrm{mM}, 0,6 \mathrm{mM})$. The result showed that isolate from LABi cattle gastric was able to grow well in MRS broth medium under anaerobic condition. In addition, it also showed catalase negative and Gram-positive bacteria. In the main experiment, this isolate was found to be resistant to low $\mathrm{pH}$ conditions (up to $\mathrm{pH}$ 2) and high concentration of sodium deoxycholate (up to 0,6 mM). These results indicate that the isolate the lactic acid bacteria have resistance to low $\mathrm{pH}$ and the sodium deoxycholate, which is the main requirement of the probiotic bacteria.
\end{abstract}

\section{Keywords: Lactic Acid Bacteria, Probiotic, Bali Cattle}

\section{INTRODUCTION}

Lactic acid bacteria (LAB) is a bacterium that is safe for its host and is able to produce compounds that can inhibit the growth of pathogenic bacteria [1]. In general the LAB is defined as a group of Grampositive bacteria, it does not produce spores, spherical or rod, catalase negative, have no cytochrome, aerotolerant anaerobic, microaerophilic bacteria until, and requires the nutrients the complex such as amino acids, vitamins (B1, B6, B12, and biotin), purin, pirimidin[2];[3].
Research on lactic acid bacteria (LAB) as a probiotic has done before, by [4] mentioning the type of LABof rumen fluid of the origin of the genus Lactobacillusis the superior candidate probiotics. Generally, the bacteria grow optimally at neutral $\mathrm{pH}$ conditions 7.0. However, generally the species LAB more tolerant of environmental conditions $\mathrm{pH}$ acidic [5]. This relates to the conditions of the digestive tract of animals that belong to have the condition with low $\mathrm{pH}$ or acid. A cow or a healthy ruminant, normally have a different $\mathrm{pH}$ along thedigestion channel, starting from reticulum-gastrict $\mathrm{pH}$ 5.3-6.5; abomasum $\mathrm{pH}$ 
2.2-4.1; and the intestineswith $\mathrm{pH}$ 5.6-6.8 [6].

\section{RESEARCH METHOD}

\section{The Cultivation of Isolates}

The cultivation of 5 isolates begins with planting the 5 isolates LAB (SR 1, SR 2, SR 3, SR 12, SR 13) by way of reculture isolates by taking each of the isolates $\mathrm{LAB}$ by using mikropipet as many as $20 \mu \mathrm{l}$, then inserted into a tube containing $5 \mathrm{ml}$ of MRS broth. Next tubes that already contains isolate of incubation temperature $37^{\circ} \mathrm{C}$ for 24 hours in an anaerobic. The success of reculture isolates characterized by the presence of turbidity on the media MRS broth.

\section{Catalase Test}

Catalase test is done to find out the presence of the enzyme catalase activity. Prepare 5 object glass for each isolate, on glass objects add $10 \mu \mathrm{l}$ LAB each isolate then added $10 \mu 1 \mathrm{H}_{2} \mathrm{O}_{2} 10 \%$.

\section{Gram Staining}

Gram staining in the 5 isolates LAB do with coloring preparations that have been fixsation using Crystal violet is $2 \%$, it is left for 1 minute 30 seconds, then washed with running water, then ditetesi liquid lugol's and left for 1 minute 30 seconds. Washed again with water flowing, then dripping with acetone and alcohol left for 30 seconds, and then washed with running water. Next tinged with safranin for 1 minute 30 seconds, then washed again with water flowing. Tinting results can be seen under a microscope with 1000 magnification. Grampositive bacteria will appear purple, while gram-negative appear red under the microscope [7].

Test for Lactic Acid Bacteria Resistance against Low $\mathrm{pH}$

Isolates $\mathrm{LAB}$ who has been through the test, catalase test, Gram staining potential of antimicrobial, immune-test performed next against low $\mathrm{pH}(\mathrm{pH} 2.3$, and 4). As many as $100 \mu \mathrm{l}$ isolates LAB which has been suspended from the stock culture of earlier research, put in a Eppendorf tube. Each of these tubes already contains $900 \mu 1$ media MRS. Broth which has adjusted its $\mathrm{pH}$ ( $\mathrm{pH} 2.3$, and 4), and then inkubasion in a waterbath temperature $37{ }^{\circ} \mathrm{C}$ for 3 hours. Furthermore, the suspension centrifuged at speeds of $3000 \mathrm{rpm}$ for 5 minutes and supernatant removed. Bacterial pellet obtained was washed twice using $300 \mu \mathrm{l}$ of solution copy with vortex and centrifuged again. Then the pellet obtained suspended, and as many as $50 \mu \mathrm{l}$ suspension is inokulasion into $5 \mathrm{ml}$ of medium MRS. Broth with a neutral $\mathrm{pH}$ for the next inkubasion at a temperature of $37^{\circ} \mathrm{C}$ for 24 hours in the anaerobic.

Test the Resistance of the Lactic Acid Bacteria against Sodium Deoxycholate

Test the resistance of the LAB against sodium deoxycholate is performed with the procreative LAB 5 isolates from stock germs into $5 \mathrm{ml}$ of medium with a $\mathrm{pH}$ of liquid in MRS. 7.2. Each of as many as $50 \mu \mathrm{l}$ of isolates that are grown into test tubes containing $5 \mathrm{~mL}$ of liquid with MRS. treat each other between the control tube (media not added liquid sodiumdeoxycholate, treatment of 1,2 , and 
3 each added as much as 10,20, and $30 \mu \mathrm{l}$, so that at each end of the concentration obtained treatment amounting to $0.2 ; 0.4$; and $0.6 \mathrm{mM}$.Furthermore all the tubes are incubated at a temperature of $37^{\circ}$ $\mathrm{C}$ for 24 hours in anaerobic. Endurance level measured by LAB isolates turbidity (OD $660 \mathrm{~nm}$ ) using a spectrophotometer. When its absorbance (A) values $<0.1$ then the strains of bacteria resistant to the is not considered, and if $\mathrm{A} \geq 0.1$ then strains resistant to LAB [8].

\section{Data Analysis}

All data are obtained from the results of this study are analyzed in a descriptive and presented in the form of tables or images.

\section{RESULTS AND ANALYSIS}

In this study, the cultivation of 5 isolates grown back was able to grow well, it is characterized by the presence of sediment on the media. Furthermore, the results of the test of catalase on the 5 isolates of lactic acid bacteria when ditetetsi with the $10 \% \mathrm{H} 2 \mathrm{O} 2$ does not produce bubbles of oxygen gas $(\mathrm{O} 2)$, this shows that the 5 isolates of lactic acid bacteria react negatively to a test of catalase. Lactic acid bacteria are generally classified into a group of anaerobic bacteria, these bacteria do not have the enzyme catalase which can break down $\mathrm{H} 2 \mathrm{O} 2$ into $\mathrm{H} 2 \mathrm{O}$ and $\mathrm{O} 2$. According to
[9],[10] stated that, the oxygen in the environment of anaerobic bacteria have properties of toxins and can inhibit the growth of anaerobic bacteria. While the Results of Gram staining isolates LAB has been done using a light microscope (magnification $1000 \mathrm{x}$ ) as presented in Figure 1 and summarized in table 1.

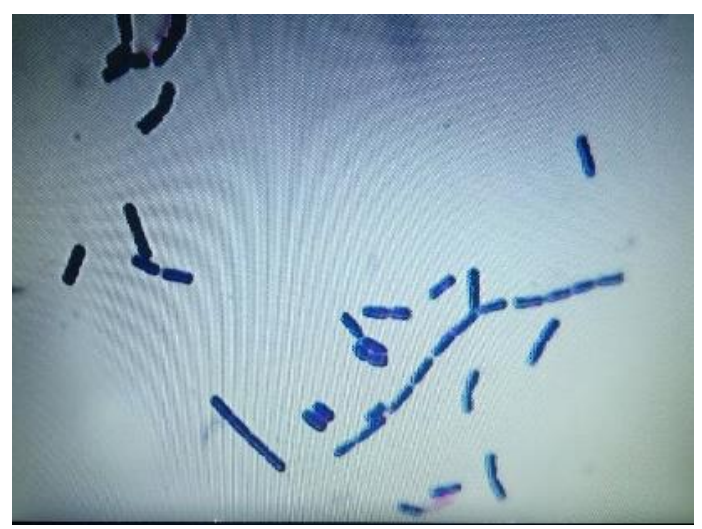

Figure 1. Gram Staining test result isolates SR 3

Pay attention to the results of the ability of the $\mathrm{LAB}$ in the 5 isolates to inhibit the growth of bacteria Staphylococcus aureus ATCC 29213 indicator, then the 5 isolates can be said to be a potential for further characterized as candidate's probiotic. As is known, generally a bacterium as a probiotic bacteria must have terms include: 1) it is resistant to acids, bile salts, and anaerobic conditions, 2) is derived from the genus secure consumed, 3) has the viability high so it stays alive, growing, and active in the gastrointestinal tract, 4) was able to inhibit or kill the pathogen bacteria [5]. 
TABLE 1. THE RESULTS OF GRAM STAINING5 ISOLATES OF LACTIC ACID BACTERIA

\begin{tabular}{cccc}
\hline Isolate & Type & Form & Aranggment \\
& & & \\
\hline SR 1 & Gram positive & Bacillus & Chain \\
SR 2 & Gram positive & Coccus & Group \\
SR 3 & Gram positive & Bacillus & Chain \\
SR 12 & Gram positive & Coccus & Chain \\
SR 13 & Gram positve & Coccus & Group \\
\hline
\end{tabular}

Further testing of 5 lactic acid bacteria isolates on their antimicrobial activity on muellerhinton media to show the formation of a fairly large diameter killing zone (Table 2).

TABEL 2. RESULT OF ANTIMICROBIAL AKTIVITY TEST FOT 5 LACTIC ACID BACTERIA ISOLATE

\begin{tabular}{cc}
\hline Isolate & $\begin{array}{c}\text { Diameter Zone } \\
\text { (Killing Zone) }(\mathrm{mm})\end{array}$ \\
\hline SR 1 & 5,4 \\
SR 2 & 5,8 \\
SR 3 & 6,4 \\
SR 12 & 6,0 \\
SR 13 & 6,0 \\
\hline
\end{tabular}

Endurance 5 isolates LAB that have been tested with a low $\mathrm{pH}$ indicates that isolates possess resistance to environment with a $\mathrm{pH}$ of $2-4$, despite a decrease in growth rate when presented at a lower $\mathrm{pH}$ (table 3). Therefore, it can be said the 5 isolates $\mathrm{LAB}$ has tolerance of low $\mathrm{pH}$. In general, the LAB has tolerance in different
$\mathrm{pH}$ conditions. Tolerance high enough LAB against acid caused due to bacteria that are able to maintain a higher intracellular $\mathrm{pH}$ than extracellular $\mathrm{pH}$ [11]. This can occur through the synthesis of the enzymes and the expenditure of a proton $(\mathrm{H}+)$ from the inside of cells that occurs through the process of hydrolysis of ATP, so an increase in the $\mathrm{pH}$ of the cytoplasm [12]. 
TABLE 3. RESISTANCE OF 5 LAB ISOLATES AT LOW PH

\begin{tabular}{|c|c|c|c|c|}
\hline \multirow[t]{2}{*}{ Isolate } & \multirow{2}{*}{$\begin{array}{c}\text { Growth Control } \\
\text { (OD pada } \lambda 660 \mathrm{~nm}) \\
\text { pH } 6,5\end{array}$} & \multicolumn{3}{|c|}{$\begin{array}{c}\text { LABGrowth } \\
\text { (Optical Density at } \lambda 660 \mathrm{~nm} \text { ) }\end{array}$} \\
\hline & & $\mathrm{pH} 2$ & $\mathrm{pH} 3$ & $\mathrm{pH} 4$ \\
\hline SR 1 & 1,327 & $1,063( \pm 0,005)$ & $1,095( \pm 0,002)$ & $1,106( \pm 0,002)^{*}$ \\
\hline SR 2 & 1,317 & $0,998( \pm 0,003)$ & $1,137( \pm 0,002)$ & $1,193( \pm 0,001)$ \\
\hline SR 3 & 1,305 & $0,964( \pm 0,003)$ & $0,998( \pm 0,003)$ & $1,127( \pm 0,002)$ \\
\hline SR 12 & 1,488 & $1,022( \pm 0,002)$ & $1,078( \pm 0,005)$ & $1,095( \pm 0,003)$ \\
\hline SR 13 & 1,300 & $1,008( \pm 0,003)$ & $1,046( \pm 0,003)$ & $1,088( \pm 0,002)$ \\
\hline
\end{tabular}

Note:

$\mathrm{OD} \geq 0.1$ (low $\mathrm{pH}$ resistant); $\mathrm{OD} \leq 0.1$ (can't stand low $\mathrm{pH}$ ), [8].

(*) The figures in the table are the result of the average of 3 repetitions ( \pm standard deviation of absorbance values isolates).

TABLE 4. RESISTANCE OF 5 ISOLATESLABATSODIUMDEOXYCHOLATE

\begin{tabular}{ccccc}
\hline & $\begin{array}{c}\text { Growth Control } \\
(\text { OD pada } \lambda 660 \\
\text { Isolate }\end{array}$ & \multicolumn{3}{c}{$\begin{array}{c}\text { LABGrowth } \\
\text { nm })\end{array}$} \\
\cline { 3 - 5 } & $\begin{array}{c}\text { (Optical Density at } \lambda 660 \mathrm{~nm}) \\
\text { withoutSodium } \\
\text { Deoxycholate }\end{array}$ & $0,2 \mathrm{mM}$ & $0,3 \mathrm{mM}$ & $0,4 \mathrm{Mm}$ \\
\hline SR 1 & 1,355 & $0,833( \pm 0,001)$ & $0,813( \pm 0,002)$ & $0,785( \pm 0,004)^{*}$ \\
SR 2 & 1,394 & $1,002( \pm 0,007)$ & $0,955( \pm 0,001)$ & $0,912( \pm 0,005)$ \\
SR 3 & 1,307 & $0,990( \pm 0,004)$ & $0,939( \pm 0,005)$ & $0,895( \pm 0,004)$ \\
SR 12 & 1,318 & $1,058( \pm 0,005)$ & $1,001( \pm 0,004)$ & $0,974( \pm 0,003)$ \\
SR 13 & 1,379 & $1,005( \pm 0,004)$ & $0,978( \pm 0,005)$ & $0,929( \pm 0,005)$ \\
\hline
\end{tabular}

Note:

$\mathrm{OD} \geq 0.1$ (low $\mathrm{pH}$ resistant); $\mathrm{OD} \leq 0.1$ (can't stand low $\mathrm{pH}$ ), [8].

(*) The figures in the table are the result of the average of 3 repetitions ( \pm standard deviation of absorbance values isolates).

On table 4 shows that the 5 isolates $\mathrm{LAB}$ has resistance to with concentrations of $0.2 \mathrm{mM}-0.6 \mathrm{mM}$, despite a decrease in growth rate when the concentration of the is getting improved. These results are in accordance with research conducted by [13] are testing the resilience of isolates of lactic acid bacteria on media containing bile salts with different concentrations, after incubated for 24 hours show an increase in microbial cell death in line with increasing concentrations of bile salts that are used in the treatment.

Good tolerance against bile salt is suspected because of the role of the polysaccharide as one of the constituent 
components of the cell walls of Grampositive bacteria as LAB [14]. Research on resistance against bile salt acidity

LAB plantarium was able to withstand the acidity of bile salts with a living cell number of 1.2 x $109 \mathrm{CFU} / \mathrm{ml}$ [15]. It is accordance with the statement of [16], that some of the genus Lactobacillus have the enzyme bile salt hydrolase $(\mathrm{BSH})$ can hydrolyze bile salts. This enzyme is able to change physical and chemical capabilities owned by bile salts, so it is not toxic for LAB. This allows to cause some isolates resistant to salt State LAB bile. However, the higher the concentration of bile salts, then the number of dead microbial cells will also increase. This is due to the increase of active

\section{CONCLUSSION}

Based on the results of the research that has been conducted against the 5 isolates, LAB results rumen fluid isolation from cattle, with the ability antimikrobial activity that is quite extensive, and have a tolerance of low $\mathrm{pH}(\mathrm{pH}$ conditions survival 2) and the relatively high concentration of (concentration of $0.6 \mathrm{mM}$ ), then it can be diaimpulkan that the 5 isolates potentially developed as candidates superior probiotic bacteria.
LAB has ever done with the result that one of the genus Lactobacillus, namely

\section{REFERENCES}

[1] Klaenhammer TR, R Barrangou, BL Buck, MA Azcarate-Peril, and E Altermann. 2005. Genomic Features of Lactic Acid Bacteria Effecting Bioprocessing and Health. FEMS Microbiol. Rev. 29: 393-409.

\begin{tabular}{llr} 
[2] Surono IS. & \multicolumn{1}{c}{ IS } \\
& ProbiotikSusuFermentasi
\end{tabular} Kesehatan. PT. Tri CiptaKarya. Jakarta.

[3] Jeevaratnam K, Jamuna M, Bawa AS. 2005. Biological preservation of foodsbacteriocins of lactic acid bacteria. Indian journal of biotechnology 4:446454.

[4] Suardana IW, Suada IK, Sukada IM, Suarsana IN.2009. Isolasi dan IdentifikasiIsolatBakteriAsamLaktat SR9 AsalCairan Rumen SapiLABisebagaiKandidatUnggulProbi otik. Medicine 40(2): 100-103.

[5] Food and Agriculture Organization of the United Nations and World Health Organization. 2002. Working Group Report on Drafting: Guidelines for the Evaluation of Probiotics in Food. London, Ontario, Canada

[6] Wheeler WE, Noller CH. 1977. Gastrointestinal Tract $\mathrm{pH}$ and Starch in Feces of Ruminants. Journal of Animal Science 44(1):131-135.

[7] Liana, S. M., A. Arfan, Merint. 2013 Isolasi dan KarakterisasiBakteriAsamLaktat pada UsusAyam Broiler. Argipet. 13(1):4348.

[8] Sujaya, I. N. M. U. Dwipayani, N. M. P. Suarini, N. P. Widarini, K. A. Nociantari, N. W. Nursini. 2008. PotensiLactobacillus spp. IsolatsusuKuda Sumbawa 
sebagaiPeobiotik. JurnalVeteriner. 9(1):33-40.

[9] Wiyana, A. 2011. Karakteristik Ketahanan Bakteri Asam Laktat Indigenous Kefir sebagai Kandidat Bakteri Probiotik pada Kondisi Saluran Pencernaan In Vitro. Skripsi, FakultasPeternakan, InstitutPertanian Bogor, Bogor.

[10] Nikita, C., and D. Hemangi. 2012.

Isolation, Identificationand Characterization of Lactic Acid Bacteria from Dairy Sludge Sample. $J$. Environ. Res. Develop. 7(1A):234-244.

[11] Hutkins, S. K., and N. L. Nanenn. 1993. $\mathrm{pH}$ Homoestatis in Lactic Acid Bacteria. Journal of Diary Science. 76 (8): 2354-2365.

[12] Chou, L. Z., and B. Weimer. 1999. Isolation and Characterzation of Acid and Bile Tolerant Isolats form Strain of Lactobacillus acidophilus. Journal of Apllied Microbiology. 87:345-352.
[13] Thamacharoensuk T, Nuttha T, Malai $\mathrm{T}$, Vasana $\mathrm{T}$, Kentaro K, Somboon T. 2013. Screeningand Characterization of Lactic Acid Bacteria from Animal Faeces for Probiotic Properties. Thai $J$ Vet Med 43(4):541-551.

[14] Wijayanto U. 2009. Analisis in Vitro ToleransiIsolatBakteriAsamLaktatAsal DagingSapiTerhadap pH Lambung, $\mathrm{pH}$ Usus dan Garam EmpedusebagaiKandidatProbiotik. (Skripsi). InstitutPertanian Bogor, Bogor.

[15] MaunatinAnik, Khanifa. 2012. Uji PotensiProbiotikLactobacillus planetarium Secara In-Vitro. Alchem. Vol. 2 No.1, hal 26-34.

[16] Smet ID, Hoorde LV, Woestyne MV, Christiaens H, Verstraete W. 1995.Significance of bile salt hydrolytic activities of lactobacilli. J. Appl. Bacteriol 79:292-301. 